\title{
LIFE CYCLE, SIZE REDUCTION PATTERNS, AND ULTRASTRUCTURE OF THE PENNATE PLANKTONIC DIATOM PSEUDO-NITZSCHIA DELICATISSIMA
}

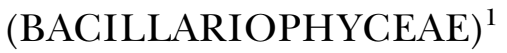

\author{
Alberto Amato, Luisa Orsini, ${ }^{3}$ Domenico D'Alelio, and Marina Montresor ${ }^{2}$ \\ Stazione Zoologica “A. Dohrn,” Villa Comunale, 80121 Naples, Italy
}

\begin{abstract}
Pseudo-nitzschia delicatissima (Cleve) Heiden is a very common pennate planktonic diatom found in temperate marine waters, where it is often responsible for blooms. Recently, three distinct internal transcribed spacer types have been recorded during a $P$. delicatissima bloom in the Gulf of Naples (Mediterranean Sea, Italy), which suggests the existence of cryptic diversity. We carried out mating experiments with clonal strains belonging to the most abundant internal transcribed spacer type. Pseudo-nitzschia delicatissima is heterothallic and produces two functional anisogametes per gametangium. The elongated auxospore possesses a transverse and a longitudinal perizonium. The sexual phase was observed to occur over a wide size spectrum, spanning $19-80 \mu \mathrm{m}$ and corresponding to almost the whole range of cell length observed for $P$. delicatissima. We also investigated cell morphology, valve ultrastructure and morphometry of parental, F1-generation strains, and the progeny of crosses between parental and F1 strains. Although ultrastructural features match those described for P. delicatissima, variability in cell shape was recorded in the largest cells of the $F 1$ generation as well as in valves with an abnormal arrangement of poroids. As many other diatoms, $P$. delicatissima undergoes size reduction over its life cycle, and cells of different size showed differences in growth rates and the amount of size reduction per cell cycle. Cells between 60 and $30 \mu \mathrm{m}$ in length showed the fastest growth and the slowest rates of size reduction per generation. In culture, $P$. delicatissima cells can decrease to $8 \mu \mathrm{m}$ in length; however, such small cells $(\leq 30 \mu \mathrm{m})$ are not recorded in the sea, and this raises interesting questions about the factors that control their survival in the natural environment.
\end{abstract}

Key index words: life cycle; morphology; Pseudonitzschia delicatissima; sexual reproduction; size reduction

Abbreviations: ITS, internal transcribed spacer; L:D, light:dark

\footnotetext{
${ }^{1}$ Received 7 July 2004. Accept 2 February 2005.

${ }^{2}$ Author for correspondence: e-mail mmontr@szn.it.

${ }^{3}$ Present address: University of Helsinki, P.O. Box 65 (Viikinkaari 1), FIN-00014 Finland.
}

Diatoms have complex life cycles, including a peculiar division mode and, in some, the capacity to produce resting stages (Round et al. 1990, Edlund and Stoermer 1997). Because of the constraint represented by the rigid silica frustule that surrounds the cell, diatoms undergo progressive size reduction as vegetative growth proceeds. Cell size is usually restored through a sexual phase, which includes the formation of a unique type of cell, the auxospore, that is not surrounded by the siliceous frustule and is therefore capable of expansion. Inside the auxospore, the formation of a large-sized vegetative cell, called the initial cell, takes place (Round et al. 1990, Mann 1993a). The basic pattern of the sexual cycle differs between centric and pennate diatoms. Centric diatoms evolved first (Kooistra et al. 2003) and are characterized by oogamous reproduction, involving the formation of uniflagellate male gametes (sperms) and larger nonmotile female gametes, whereas pennates produce nonmotile morphologically identical but sometimes behaviorally different gametes (Round et al. 1990). Within these two major types, there are many variants characterized by distinct morphological and behavioral traits, which may be helpful in revealing evolutionary relationships among taxa (von Stosch 1982, Theriot 1992, Mann 1999).

A critical link between diatom cell size and the onset of the sexual phase has been reported for several species: Gametogenesis generally occurs within cells of the smaller size classes, usually below $30 \%-40 \%$ of the dimensions of the maximum cell size (Round et al. 1990). In addition, vegetative enlargement has been reported for a few diatoms, for example, the centric diatoms Ditylum brightwellii (West) Grunow (von Stosch 1965), Leptocylindrus danicus Cleve (French and Hargraves 1985), and Skeletonema costatum (Greville) Cleve (Gallagher 1983) and the pennate diatom Achnanthes (Chepurnov and Mann 1997). These species are able to regain a larger size while bypassing the sexual phase: Cells inflate, producing an auxospore-like structure, and then build a new and larger pair of valves (von Stosch 1965, Gallagher 1983, Nagai et al. 1995).

Life histories have important implications for diatom ecology. Undergoing a sexual phase is crucial for many diatom species to regain cells with a larger size. Moreover, sex allows for genetic recombination, and the frequency of sexual events should have a fundamental role in shaping the genetic structure of diatom 
populations. A variety of sexual strategies with different levels of synchronization and triggering modes has been reported and correlated with ecological factors (McQuoid and Hobson 1996, Edlund and Stoermer 1997). However, life history patterns, including the sexual cycle, have been investigated for only a very limited number of species, if we consider the extreme evolutionary, morphological, and ecological diversity of this group of marine algae. Most studies have dealt with freshwater benthic species (Geitler 1979, Mann 1993a, Mann et al. 2003), and relatively little information is available for marine planktonic diatoms (Edlund and Stoermer 1997, Mann 1993b).

We describe the life cycle of Pseudo-nitzschia delicatissima (Cleve) Heiden, a chain-forming marine pennate diatom, with a wide distribution range in both oceanic and coastal waters (Hasle 2002). Species identification within the genus Pseudo-nitzschia is often troublesome and requires the examination of fine ultrastructural characters of the silica frustule in TEM (Hasle and Syvertsen 1997). A recent study carried out in the Gulf of Naples (Mediterranean Sea) showed that distinct internal transcribed spacer (ITS) types are present within $P$. delicatissima (Orsini et al. 2004). The ITS types are indistinguishable in the light microscope, and two of them share the same TEM ultrastructure previously reported for $P$. delicatissima (Hasle and Syvertsen 1997, Skov et al. 1999); a third ITS type can be differentiated by a slightly different arrangement of the poroids on the valve surface. The different genotypes might represent cryptic "biological" species; that is, although they may share the same or very similar ultrastructural characters, they might be reproductively isolated (Mann 1999). Mating experiments should be carried out to test this hypothesis. We report here on an investigation of several strains belonging to the most abundant ITS type recorded in our area (Orsini et al. 2004). The aim was to describe the sexual cycle in light microscopy (LM) and scanning electron microscopy (SEM) and gain information on the range of variability of ultrastructural features used for species identification. We also studied the pattern of cell size reduction during vegetative growth and performed mating experiments using strains of different size to find the cell size window in which sexual reproduction occurs.

\section{MATERIALS AND METHODS}

Cultures. The clonal strains of $P$. delicatissima used in this investigation (P1-P4, originally clones 18-02, 24-02, 26-02, and 27-02; Table 1) are those studied by Orsini et al. (2004), who obtained sequence data for hypervariable domains of the large subunit and ITS rDNA. Strain P5 (designated 14V in our records), isolated from coastal waters in Vigo (Spain), was also studied, because it belongs to the same ITS and large subunit clade as the strains obtained from the Gulf of Naples (GenBank accession no. AY764136). Cultures were maintained in Petri dishes filled with $30 \mathrm{~mL}$ of f/2 medium (Guillard 1983) at a temperature of $20^{\circ} \mathrm{C}$ and with a 12:12-h light:dark (L:D) photocycle and a photon fluence rate of about $100 \mu \mathrm{mol}$ photons $\cdot \mathrm{m}^{-2} \cdot \mathrm{s}^{-1}$. Cultures of $\mathrm{F} 1$ and $\mathrm{F} 2$ generation strains were established by the isolation of single initial cells and maintained as described above.

Mating experiments. Mating experiments between parental strains were performed on different occasions during the progressive size reduction of the cultures. Before running the experiments, 30 cells of each strain were measured at $400 \times$ magnification using an Axiophot light microscope (Carl Zeiss, Oberkochen, Germany) equipped with an ocular micrometer. Cultures in exponential growth phase (approximately $5 \times 10^{4}$ cells $\cdot \mathrm{mL}^{-1}$ ) were used for testing mating compatibility. Pairs of strains were inoculated together into tissue-culture plate wells filled with $5 \mathrm{~mL}$ of $\mathrm{f} / 2$ medium and incubated at a temperature of $20^{\circ} \mathrm{C}$, a photon fluence rate of about $100 \mu \mathrm{mol}$ photons $\cdot \mathrm{m}^{-2} \cdot \mathrm{s}^{-1}$, and a $14: 10-\mathrm{h} \mathrm{L:D} \mathrm{photo-}$ cycle. Control wells were inoculated with double the volume $(0.4 \mathrm{~mL})$ of each parental strain to test for the presence of intraclonal sexual reproduction. Culture plates were inspected daily with a Zeiss Axiovert inverted microscope to check for the presence of sexual stages. The different life stages were observed and measured via a Zeiss Axiovert and/or Axiophot microscope and photographed using a Zeiss Axiocam digital system. The presence and arrangement of the chloroplasts in the auxospores were observed with the Zeiss Axiophot microscope using the Zeiss epifluorescence filter set 487901. Small amounts of cultures containing sexual stages were prepared for SEM as described below.

Four F1 generation strains (Table 1) from each of two crossing experiments $(\mathrm{P} 1 \times \mathrm{P} 2$ and $\mathrm{P} 3 \times \mathrm{P} 4)$ and three from another crossing experiment $(\mathrm{P} 2 \times \mathrm{P} 4)$ were established by the isolation of a single initial cell within a day of the completion of auxospore expansion. These strains were crossed among each other and with the parental strains to test their reproductive success. Experiments were carried out using the same protocol as described above.

EM preparations. Subsamples of all parental strains used for mating experiments, of selected strains of the F1 generation, and of strains obtained from additional crosses were prepared for TEM as described by Orsini et al. (2004) and observed with an EM 400 microscope (Philips, Eindhoven,

Table 1. Strains of Pseudo-nitzschia delicatissima used.

\begin{tabular}{|c|c|c|c|}
\hline Strain & $\begin{array}{c}\text { Original } \\
\text { designation }\end{array}$ & Generation & Origin of strain \\
\hline $\mathrm{P} 1$ & $18-02$ & Parental & MareChiara, Gulf of Naples ${ }^{a}$ \\
\hline $\mathrm{P} 2$ & 24-02 & Parental & MareChiara, Gulf of Naples ${ }^{a}$ \\
\hline P3 & $26-02$ & Parental & MareChiara, Gulf of Naples ${ }^{a}$ \\
\hline P4 & 27-02 & Parental & MareChiara, Gulf of Naples ${ }^{a}$ \\
\hline P5 & $14 \mathrm{~V}$ & Parental & Coastal waters, Vigo, Spain \\
\hline F1-1 & $6-1$ & $\mathrm{~F} 1$ & $\mathrm{P} 1 \times \mathrm{P} 2$ progeny \\
\hline F1-2 & $6-3$ & F1 & $\mathrm{P} 1 \times \mathrm{P} 2$ progeny \\
\hline F1-3 & $6-13$ & F1 & $\mathrm{P} 1 \times \mathrm{P} 2$ progeny \\
\hline F1-4 & $6-43$ & F1 & $\mathrm{P} 1 \times \mathrm{P} 2$ progeny \\
\hline F1-5 & $42-02$ & F1 & $\mathrm{P} 2 \times \mathrm{P} 4$ progeny \\
\hline F1-6 & $42-07$ & F1 & $\mathrm{P} 2 \times \mathrm{P} 4$ progeny \\
\hline F1-7 & $42-08$ & F1 & $\mathrm{P} 2 \times \mathrm{P} 4$ progeny \\
\hline F1-8 & $42-09$ & F1 & $\mathrm{P} 2 \times \mathrm{P} 4$ progeny \\
\hline F1-9 & $45-16$ & F1 & $\mathrm{P} 3 \times \mathrm{P} 4$ progeny \\
\hline F1-10 & $45-23$ & $\mathrm{~F} 1$ & $\mathrm{P} 3 \times \mathrm{P} 4$ progeny \\
\hline F1-11 & $45-28$ & F1 & $\mathrm{P} 3 \times \mathrm{P} 4$ progeny \\
\hline F1-12 & $45-49$ & F1 & $\mathrm{P} 3 \times \mathrm{P} 4$ progeny \\
\hline F1-13 & $45-60$ & F1 & $\mathrm{P} 3 \times \mathrm{P} 4$ progeny \\
\hline F1-14 & $45-61$ & F1 & $\mathrm{P} 3 \times \mathrm{P} 4$ progeny \\
\hline F2-1 & 219 & $\mathrm{~F} 2$ & $\mathrm{~F} 1-3 \times \mathrm{F} 1-4$ progeny \\
\hline F2-2 & 199 & $\mathrm{~F} 2$ & $\mathrm{~F} 1-2 \times \mathrm{F} 1-12$ progeny \\
\hline BC1 & 167 & Backcross & $\mathrm{P} 4 \times \mathrm{F} 1-3$ progeny \\
\hline BC2 & 145 & Backcross & $\mathrm{P} 2 \times \mathrm{F} 1-10$ progeny \\
\hline
\end{tabular}

${ }^{\mathrm{a} C l o n e s ~ f r o m ~ M a r e C h i a r a ~ s t u d i e d ~ a l s o ~ b y ~ O r s i n i ~ e t ~ a l . ~(2004) . ~}$ 
The Netherlands). Morphometric analyses were always made in the central part of the bands, because the poroid pattern sometimes changed toward the band apex. For observation of sexual stages by SEM, cultures in which sexual reproduction occurred were fixed with glutaraldehyde (final concentration, $1.5 \% \mathrm{v} / \mathrm{v}$ ) and gently concentrated by gravity on a polycarbonate filter (Nucleopore, Pleasanton, CA, USA), placed in a Sweenex filter holder. Samples were dehydrated in a graded ethanol series, critical point dried, sputtered with gold, and observed with a Philips 505 SEM. Cultures with sexual stages were prepared also for SEM microanalysis to detect any silica present in the early stages of the auxospore development. In this case, samples were sputtered with carbon instead of gold and microanalysis was performed using a 250 MARK 3 scanning electron microscope (Cambridge Instruments, Cambridge, UK) equipped with an XRMA system LINK AN10000. The operational parameters were as follows: lifetime, $150 \mathrm{~s}$; accelerating voltage, $15 \mathrm{kV}$; working distance, $30 \mathrm{~mm}$; and detector take-off angle, 25 degrees. The program was preset to show $\mathrm{Na}, \mathrm{Al}, \mathrm{Si}, \mathrm{P}, \mathrm{S}$, and $\mathrm{Cl}$. Polycarbonate filters and vegetative cells were used as negative and positive controls, respectively.

Size reduction in vegetative cells. Size reduction was examined in three F1 strains: F1-5, F1-12, and F1-13 (Table 1). Half-strength f/2 medium (f/4), prepared with artificial seawater (ASW Sigma Sea Salt, Sigma, St. Louis, MO, USA), was used as the growth medium to rule out any possible effect of different stocks of natural seawater. After isolation, cultures were grown in a tissue-culture plate well until a concentration of about 600 cells $\cdot \mathrm{mL}^{-1}$ was reached. They were then transferred into a Petri dish and finally into $70-\mathrm{mL}$ tissue culture flasks filled with $45 \mathrm{~mL}$ of $\mathrm{f} / 4$ medium (initial cell concentration of about 500 cells $\cdot \mathrm{mL}^{-1}$ ). Flasks were placed on a Ferris wheel $(0.3 \mathrm{rpm})$ in a growth chamber at a temperature of $20^{\circ} \mathrm{C}$, a photon fluence rate ranging between 400 (upper position, close to the light bulbs) and 220 (lower position) $\mu$ mol photons $\cdot \mathrm{m}^{-2} \cdot \mathrm{s}^{-1}$, and a $14: 10-\mathrm{h} \mathrm{L}: \mathrm{D}$ photocycle to simulate the conditions recorded at sea during the spring bloom of $P$. delicatissima (Ribera d'Alcalà et al. 2004). Cultures were maintained in exponential growth through sequential dilutions. For the first 2 months and during a later check between days 139 and 153, dilutions were coupled with estimations of cell growth rates. For the rest of the experiment, dilutions were not performed quantitatively. A subsample was collected and fixed with neutralized formaldehyde (final concentration, $1.6 \% \mathrm{v} / \mathrm{v})$ to estimate cell concentration. Cultures were then diluted with fresh growth medium to restore the initial cell concentration (approximately 500 cells $\cdot \mathrm{mL}^{-1}$ ). Cell concentrations were estimated with a $1-\mathrm{mL}$ Sedgwick-Rafter counting chamber. Growth rates, expressed as divisions $\cdot$ day $^{-1}$, were calculated for the time intervals between two successive dilutions using the formula $\mathrm{k}_{2=}\left[\log _{2}\left(C_{1} / C_{0}\right)\right] /\left(t_{1}-t_{0}\right)$, where $\mathrm{k}_{2}$ is the number of cell divisions per day; $C_{1}$ and $C_{0}$ are cell concentrations at time $t_{1}$ and $t_{0}$, respectively; and $\left(t_{1}-t_{0}\right)$ is the time interval between the inoculum $\left(t_{0}\right)$ and the dilution $\left(t_{1}\right)$, expressed in days. Dilutions were always performed at the same time of the day. The lengths of 40 cells were measured using a Zeiss Axiophot microscope $(400 \times$ magnification) every $10-15$ days.

The size reduction rate (expressed as $\mu \mathrm{m} \cdot$ generation $^{-1}$ ) was calculated for the time intervals between two successive sets of cell size measurements. The formula $R=\left(L_{\mathrm{e}}-L_{\mathrm{s}}\right) \times G^{-1}$ was applied, where $R$ is the size reduction rate; $L_{\mathrm{e}}$ and $L_{\mathrm{s}}$ are the mean apical lengths recorded at time $t_{\mathrm{e}}(=\mathrm{end})$ and $t_{\mathrm{s}}$ (=start), respectively; $\left(t_{\mathrm{e}}-t_{\mathrm{s}}\right)$ is the time interval between two successive sets of cell measurements; and $G$ is the total number of generations in the time interval $\left(t_{\mathrm{e}}-t_{\mathrm{s}}\right)$. $G$ was calculated using the formula $G=\Sigma_{\mathrm{i}} \log _{2}\left(C_{i} / C_{i-1}\right)$, where $C_{i}$ and $C_{i-1}$ are cell concentrations at the end $\left(C_{i}\right)$ and at the beginning $\left(C_{i-1}\right)$ of the dilution intervals.

\section{RESULTS}

Morphology of the parental strains. In LM, clones identified as $P$. delicatissima were characterized by a lanceolate shape in both girdle (Fig. 1a) and valvar view (Fig. 1b). In girdle view, cells had truncated apices and formed stepped chains by the overlapping of the valve ends (Fig. 1a). The overlapping region ranges between $1 / 7$ and $1 / 9$ of the cell. All strains (parent and progeny) observed in this work were $1.3-2 \mu \mathrm{m}$ wide over almost the whole size range. In TEM, two rows of circular poroids were visible within each stria (Fig. 1c). The central interspace (Fig. 1c) was larger, and here the raphe was interrupted. The numbers of striae and fibulae in $10 \mu \mathrm{m}$ were 33-43 and 22-29, respectively, and the number of poroids in $1 \mu \mathrm{m}$ was $8-11$ (Table 2).

The epicingulum contained three open bands, whose height decreased toward the extremities of the cell. The first cingular band (= valvocopula) was ornamented by one row of square to slightly rounded poroids, which were subdivided into two (Fig. 1, d and e), three, or four (Fig. 1f) sectors by weakly silicified bridges. The density of striae on the valvocopula was $44-53$ in $10 \mu \mathrm{m}$. The ornamentation of the valvocopula varied slightly among strains, and the number of sectors per poroid changed along the band length, except in strain P1, where we always observed valvocopulae with poroids split into two sectors all along the band (Fig. 1e). The abvalvar margin of the valvocopula was rather narrow (1/4-1/3 of the band width) and not ornamented. The second band possessed a single row of rectangular poroids, each divided into two sectors (Fig. $1, \mathrm{~d}$ and $\mathrm{g}$ ). The stria density was $44-51$ in $10 \mu \mathrm{m}$. The abvalvar margin was not ornamented, with the exception of strain P4, where there was a faint ornamentation, comprising a single row of perforations (Fig. 1h); in this case, the abvalvar margin was similar in size to the ornamented portion of the band. The third band was plain and nonporous (Fig. 1, d and i), except in strain $\mathrm{P} 4$, where faint more silicified markings were sometimes visible (Fig. 1j). A longitudinal rib separated the band into two halves.

Cell shape changed strikingly during the process of size reduction. In old cultures (cell length, 10-20 $\mu \mathrm{m}$ ), most cells had an undulate shape and the fibulae, striae, and the raphe slit were often aberrant, being distorted and sometimes interrupted (Fig. 1k). However, the densities of the striae and fibulae and the poroid densities of the valve and the cingular bands did not change.

Sexual reproduction. Pseudo-nitzschia delicatissima is heterothallic. Auxospore formation occurred only when two strains, belonging to opposite mating types, were present (Table 3). In the first stages of the investigation, strains were arbitrarily assigned to a " + " or "- " mating type based on the results of the crossing 


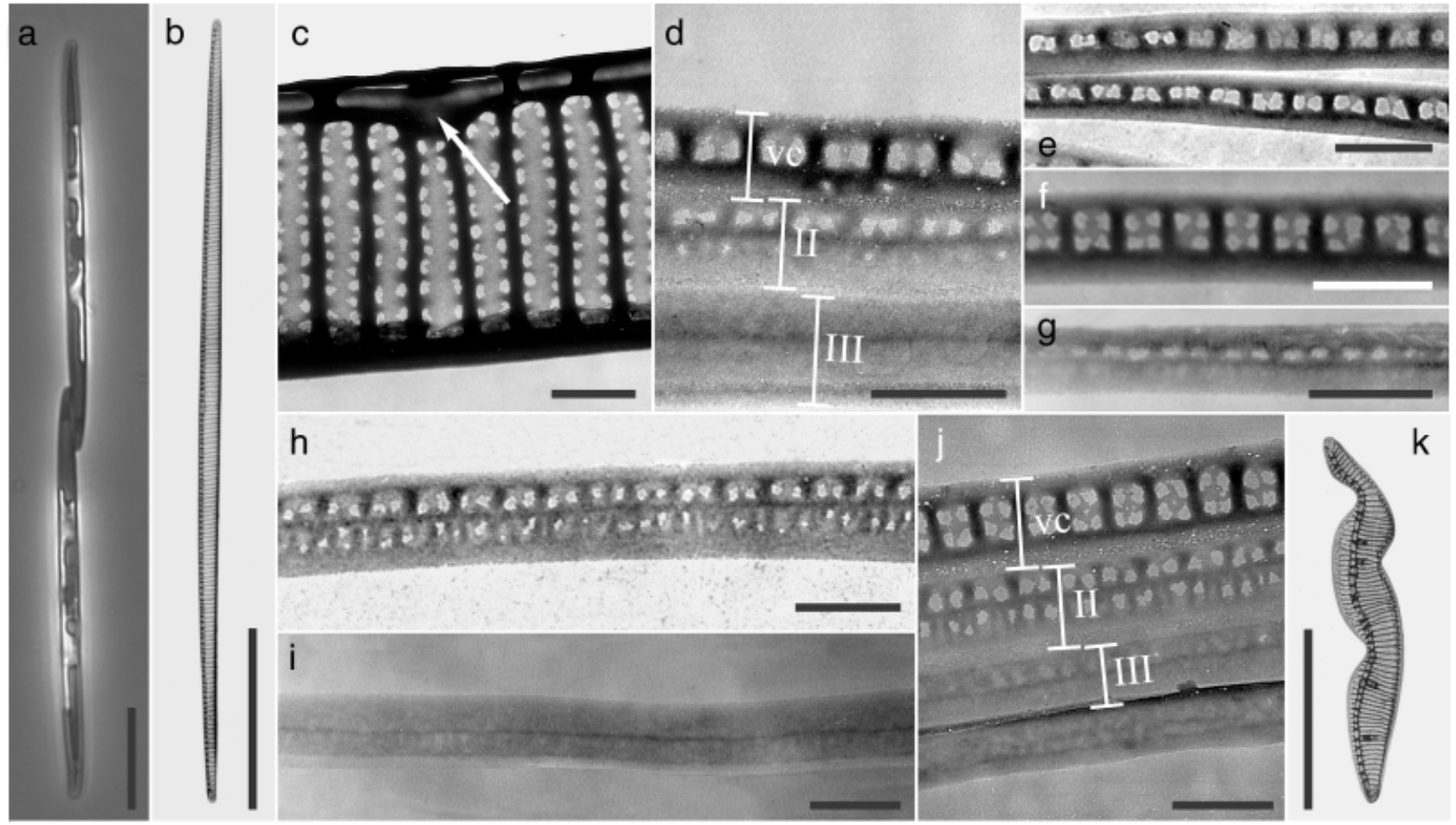

FIG. 1. Pseudo-nitzschia delicatissima: valve and cingular band morphology in LM (a) and TEM (b-k). (a) A two-celled chain in girdle view. Strain P1. (b) A valve. Strain P1. (c) Central portion of the valve; the central larger interspace is marked with an arrow. Strain P2. (d) Valvocopula (vc), second (II) and third (III) cingular band. Strain P3. (e) Valvocopula with poroids split into two sectors. Strain P1. (f) Valvocopula with poroids split into three and four sectors. Strain P3. (g) Second cingular band. Strain P2. (h) Second cingular band. Strain P4. (i) Third cingular band. Strain P1. (j) Valvocopula (vc), second (II) and third (III) cingular bands. Strain P4. (k) Undulate valve in an old culture of strain P4. Scale bars: $0.5 \mu \mathrm{m}(\mathrm{c}-\mathrm{j}), 10 \mu \mathrm{m}(\mathrm{a}, \mathrm{b}, \mathrm{k})$.

experiments. However, experiments involving strains markedly different in length allowed us to properly identify the "passive" strains as those whose cells bore the auxospores, remaining attached to them during early development. Based on these results, we reassigned the correct mating type to all strains. Auxosporulation was never observed in culture wells containing the single strains or in wells in which two strains belonging to the same mating type were inoculated. Monoclonal cultures showed a progressive reduction of cell size, and large cells were never observed to be formed, even when the vegetative cells had become very small (well below $30 \mu \mathrm{m}$ ).

Mating experiments were always started in the morning (between 9:00 and 11:00 a.m.), and the first sexual stages-paired cells-were observed at the end of the second dark phase. Pairing usually occurred between solitary gametangia but could occasionally occur between a solitary cell and one that was part of a chain. Two elliptical morphologically identical gametes were produced within each gametangium (Fig. 2a, arrow). Neither copulation tubes nor mucilage envelopes were ever observed. We were not able to observe plasmogamy, but we assume that two motile gametes from one gametangium migrated into the other one, because both zygotes were formed on the same gametangium (Fig. 2, b, d, h, and i). At the beginning of the second light cycle, numerous small auxospores were present. The zygotes (early auxospores) were initially spherical and surrounded by a largely organic membrane (Fig. 2, $c$ and d). The auxospores adhered to one cingular band of the parental frustule via a mucous pad (Fig. 2e, arrow). Soon after its formation, the zygote started elongating and its external membrane appeared to be wrinkled (Fig. 2e), despite care to prepare material for SEM with the minimum of distortion. The number of auxospores in the culture plates reached a maximum in the middle of the third light cycle. Usually, each gametangial pair produced two auxospores, but gametangia bearing only one auxospore were occasionally observed. The auxospores expanded almost parallel to each other and perpendicular to the gametangia (Fig. 2, h and i). The elongation of the two auxospores was slightly asynchronous (Fig. 2, h and i), and at times one auxospore did not develop or grow.

The SEM microanalysis (Fig. 3, a-d) showed the presence of silicon in the wall of the early stages (Fig. 3a) and mature auxospores (Fig. 3b). However, no silica scales were visible on the auxospore. The original external membrane of the zygote was broken during auxospore elongation, and the two halves were forced apart by expansion of the auxospore and the accompanying the deposition of the silica bands of the perizonium (Fig. 2f). Each half of this external membrane 
TABLE 2. Morphometric data of parental, F1 generation, and other strains of Pseudo-nitzschia delicatissima (with the number of TEM pictures on which measurements were taken in parenthesis) and a summary of the data reported in the literature.

\begin{tabular}{lccc}
\hline \hline Strain & $\begin{array}{c}\text { Striae in } \\
10 \mu \mathrm{m}(n)\end{array}$ & $\begin{array}{c}\text { Fibulae in } \\
10 \mu \mathrm{m}(n)\end{array}$ & $\begin{array}{c}\text { Poroids in } \\
1 \mu \mathrm{m}(n)\end{array}$ \\
\hline Parental strains & & & \\
\hline P1 & $33-35$ & 22 & $8-11(2)$ \\
P2 & $33-35$ & 22 & 9 \\
P3 & 36 & 24 & 9 \\
P4 & $35-40$ & 23 & $9-10(3)$ \\
P5 & $40-43$ & $22-29$ & $8-10(10)$ \\
Range & $33-43(22)$ & $22-29(14)$ & $8-11(17)$
\end{tabular}

F1 generation

\begin{tabular}{lccc}
\hline F1-1 & $38-40$ & $21-22$ & 8 \\
F1-2 & 42 & $24-28$ & 10 \\
F1-3 & $38-42$ & $22-28$ & $8-11$ \\
F1-4 & $40-41$ & $23-26$ & 10 \\
F1-7 & 38 & 25 & 9 \\
F1-8 & 39 & 24 & $8-10$ \\
F1-9 & 40 & 23 & - \\
F1-10 & $41-42$ & $22-25$ & $8-11$ \\
F1-11 & 40 & $23-28$ & $6-7$ \\
F1-12 & 37 & 25 & $-11(13)$ \\
Range & $37-42(15)$ & $21-28(16)$ & $6-11$
\end{tabular}

F2 and backcross progeny

\begin{tabular}{lcll}
\hline F2-1 & 40 & $22-24$ & $8-10$ \\
F2-2 & $38-41$ & 23 & 9 \\
BC1 & 38 & $21-23$ & $7-10$ \\
BC2 & 37 & $21-24$ & $6-8$ \\
Range & $37-41(12)$ & $21-24(8)$ & $6-10(8)$
\end{tabular}

Other records

\begin{tabular}{lccc}
\hline $\begin{array}{l}\text { P. delicatissima } \\
\text { (Hasle 1965) }\end{array}$ & $36-40$ & $19-25$ & $10-12$ \\
$\begin{array}{l}\text { P. delicatissima } \\
\text { (Hasle et al. 1996) }\end{array}$ & $\sim 40$ & $20-23$ & $10-12$ \\
$\begin{array}{l}\text { P. delicatissima } \\
\text { (Skov et al. 1999) }\end{array}$ & $37-43$ & $20-26$ & $8-12$ \\
\hline
\end{tabular}

formed a cap adhering on each pole of the auxospore (Fig. 2f, arrows). The distal part of the auxospore underneath the cap appeared truncate and was closed by a thin membranous operculum. The operculum was broken during escape of the initial cell, leaving a rim like unpicked sewing (Fig. 2, $\mathrm{k}$ and $\mathrm{j}$ ).

Table 3. Matrix of crosses between parental strains of Pseudo-nitzschia delicatissima.

\begin{tabular}{lccccc}
\hline \hline Strain & P1 & P2 & P3 & P4 & P5 \\
\hline m.t. & + & - & - & + & + \\
P1 & No & Yes & Yes & No & No \\
P2 & & No & No & Yes & Yes \\
P3 & & & No & Yes & Yes \\
P4 & & & & No & No \\
P5 & & & & & No \\
\hline
\end{tabular}

m.t., mating type attributed, based on the results of crosses; yes, sexual stages observed; no, sexual stages not observed.
The bands of the transverse perizonium were open hoops, whose ends turned centripetally to form $\mathrm{V}$-shaped markings on the ventral part of the auxospore (Fig. 2, $\mathrm{f}$ and $\mathrm{g}$ ). In the central portion, the auxospore appeared slightly inflated and the V-shaped markings were not always clearly visible (Fig. $2 \mathrm{~g}$, circle). The auxospore was also characterized by the presence of a longitudinal (internal) perizonium that, however, only became visible inside the empty transverse perizonium (Fig. 2l, arrow) after the initial cell had escaped.

Almost all the volume of the auxospore was occupied by a large vacuole and four chloroplasts (Fig. 2, h and i), which was clearly visible in epifluorescence microscopy (not shown). During the maturation process, chloroplasts migrated along the auxospore. In early and medium-grown auxospores, two chloroplasts were located in the central part and two at the poles, one at the distal and one at the proximal pole (Fig. 2h). In late maturation stages, the two chloroplasts at the poles moved toward the central portion of the auxospore (Fig. 2i, auxospore on the right). However, the initial cell produced inside the auxospore seemed to contain only two chloroplasts (Fig. 2i, auxospore on the left), as in all vegetative cells. It was not possible to determine whether two of the four chloroplasts degenerated or if they fused two by two, yielding the two chloroplasts located on each side of the nucleus. The valves of the initial cell were deposited asynchronously within the perizonium.

At times, the initial cell divided when still inside the auxospore (Fig. $2 \mathrm{~m}$ ) and the daughter cells were released from the auxospore as a two-celled chain (Fig. $2 n)$. We also observed up to four cells linked by the proximal valve apices emerging from the auxospore (Fig. 2o). Initial cells (Fig. 2p) were measured when their formation was complete but while they were still enclosed in the auxospore. The average lengths of initial cells obtained from crosses $\mathrm{P} 3 \times \mathrm{P} 4$ and $\mathrm{P} 2 \times \mathrm{P} 4$ were $84.6 \pm 2.65$ and $85.9 \pm 2.78 \mu \mathrm{m}( \pm \mathrm{SD}, n=50)$, respectively (Fig. 4 ).

All the F1 generation strains established from the isolation of initial cells were healthy. Sexual stages were observed when, after size reduction, F1 strains were crossed with each other and with parental strains; their mating types remained constant throughout.

Size window for sexual reproduction. Mating experiments were performed several times, spanning the time interval (11 months) between culture establishment and extreme size reduction (Table 4). On 27 January 2003, the cross P2 $\times$ P4 was fertile, with the formation of auxospores and initial cells, whereas the cross $\mathrm{P} 3 \times \mathrm{P} 4$ was not fertile, suggesting that strain P3 had reached the limiting size at which sexuality is no longer possible. About 1 month later, both crosses were unsuccessful (Table 4). The parental strain P4 was subsequently crossed with strain F1-6 to test the upper size range for sexual reproduction. The cross was successful, thus demonstrating that $\mathrm{P} 4$ was still potentially 


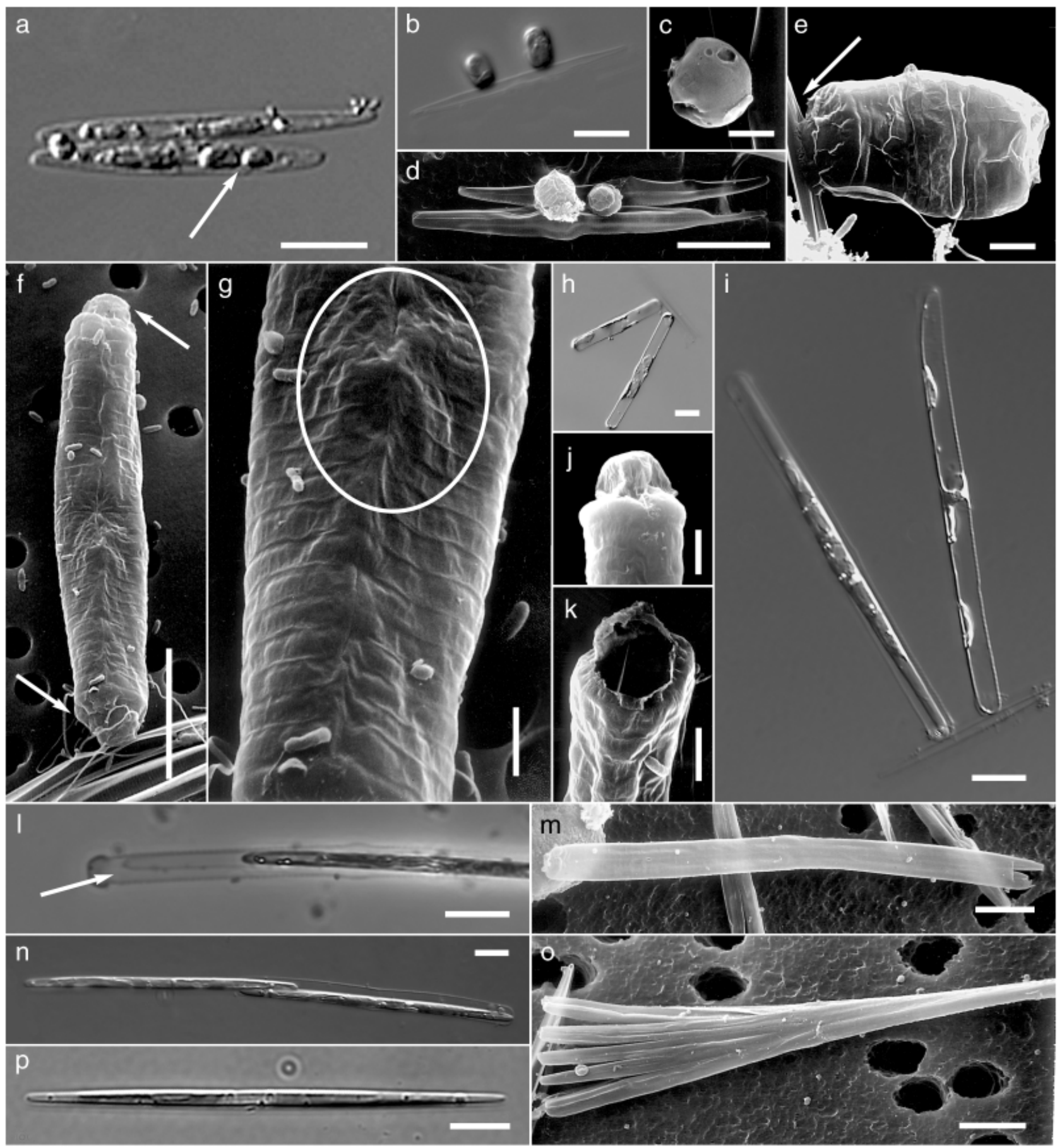

FIG. 2. Sexual reproduction stages of Pseudo-nitzschia delicatissima (cross P3 $\times$ P4) in LM (a, b, h, i, l, n, p) and SEM (c-g, j, k, m, o). (a) Paired gametangia with fusing gametes (arrowed). (b) Two early-stage auxospores attached to the empty gametangial frustule. (c) Rounded zygote with smooth surface. (d) Early auxospores at different maturation stages. (e) Early-stage auxospore adhering to the parental frustule by a mucus pad (arrowed). (f) An auxospore in ventral view; the proximal and the distal caps are arrowed. (g) Central portion of an auxospore in ventral view; the poorly organized band pattern in the center is encircled. (h) Two auxospores. (i) Two mature auxospores; the initial cell is visible within the auxospore on the left. (j) Apical portion of a mature auxospore showing the operculum-like cap. (k) Apical portion of an open auxospore. (l) An initial cell escaping from the auxospore; the longitudinal perizonium is arrowed. (m) Two initial cells still surrounded by the auxospore. (n) A two-celled chain escaping the auxospore. (o) Four initial cells still partially surrounded by the auxospore. (p) Initial cell. Scale bars: $10 \mu \mathrm{m}$ (a, b, d, f, h, I, and l-p), $2 \mu \mathrm{m}(\mathrm{c}, \mathrm{e}, \mathrm{g}, \mathrm{j}, \mathrm{k})$.

sexually active, notwithstanding its very small size, but could reproduce only when crossed with a significantly larger strain.
Morphology of F1 and F2 generations. The shape of vegetative cells of strains belonging to the F1 generation presented subtle differences as compared with 


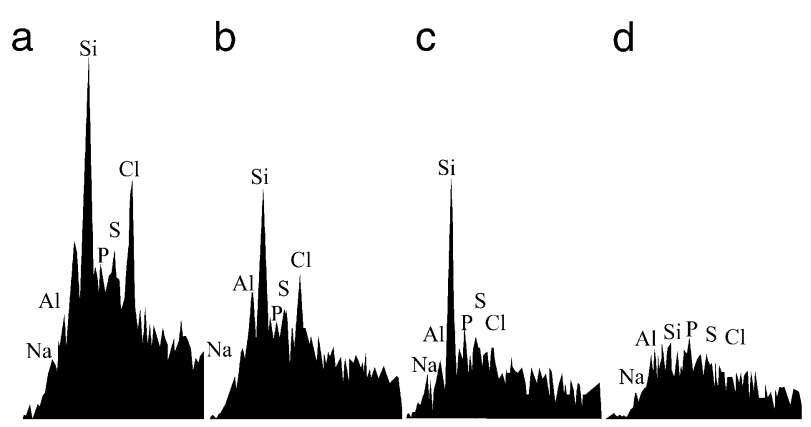

FIG. 3. Diagrams illustrating the elemental composition of (a) zygote (see Fig. 2c) and (b) auxospore (see Fig. 2f) obtained by qualitative SEM microanalysis. A parental frustule (c) (see Fig. 2d) and the Nucleopore polycarbonate filter (d) were used as controls.

the parental ones. Besides normal cells with truncated apices (Fig. 5a), cells with pointed apices (Fig. 5b) were often found in the same culture. Moreover, cells could be either isopolar (both apices were either truncated or pointed; Fig. 5c) or heteropolar (with one apex of each type; Fig. 5d). Ultrastructural features of the frustules of F1 strains (Fig. 5, e-g) examined within a few weeks from the establishment of the cultures were in the range of those recorded for the parental strains (Table 2). Strains obtained by crossing two F1 strains or an F1 and a parental strain (different from the parental strains from which the F1 was derived) also produced a high number of cells with pointed apices (Fig. 5, h and i), together with cells with a normal outline (Fig. 5j). However, in F2 or backcross strains, we did not observe heteropolar cells. The TEM analyses of F2 and backcross strains usually showed ultrastructural features of the valve in the range of those reported for $\mathrm{F} 1$ and parental strains (Fig. 5, k and l). A slightly different structure and arrangement of poroids was observed in valves of BC2, where some striae were ornamented with two rows of normal circular poroids, whereas others had a single row of oval poroids split into two sectors by silica bridges (Fig. $5 \mathrm{~m}$ ). The number of poroids ranged between six and eight in $1 \mu \mathrm{m}$ (Table 2). These atypical valves were sporadically observed also in strains BC1 and F2-2. The cell widths of

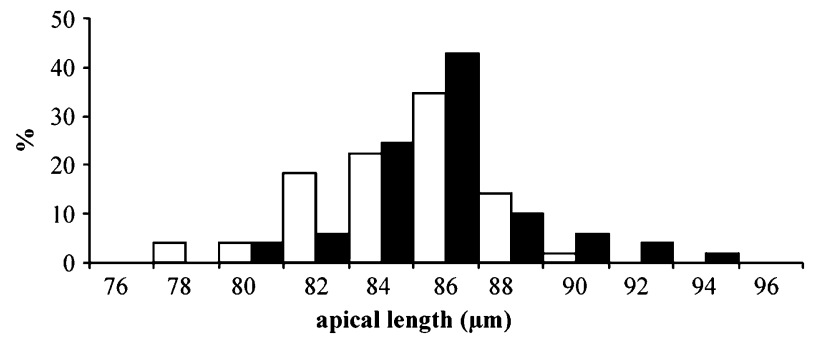

FIG. 4. Size distribution of the apical axis length of initial cells obtained by crossing strains P2 $\times$ P4 (black bars) and P3 $\times$ P4 (white bars); 50 initial cells were measured for each cross.

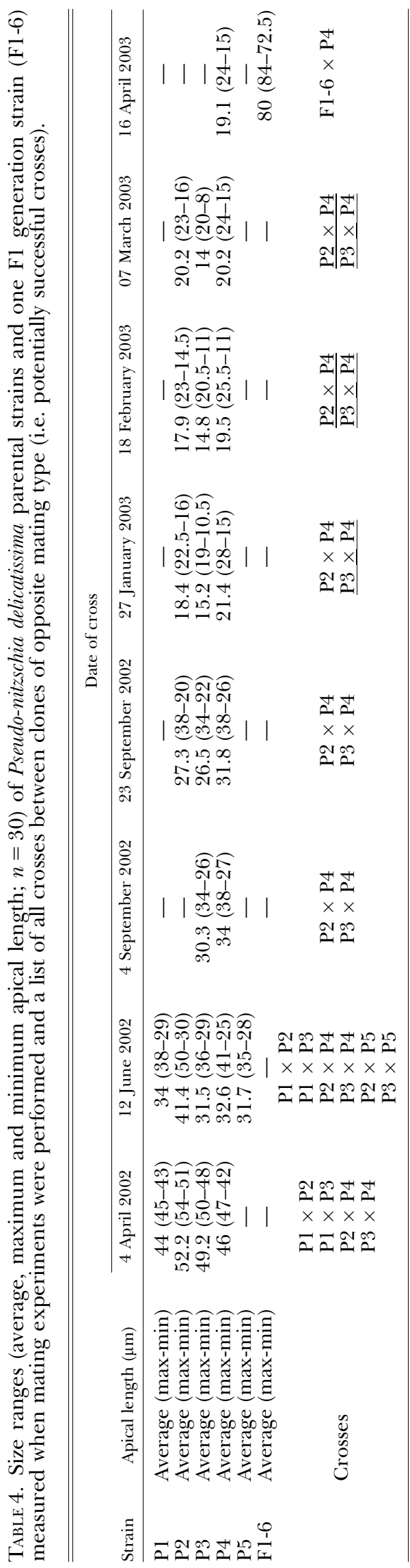



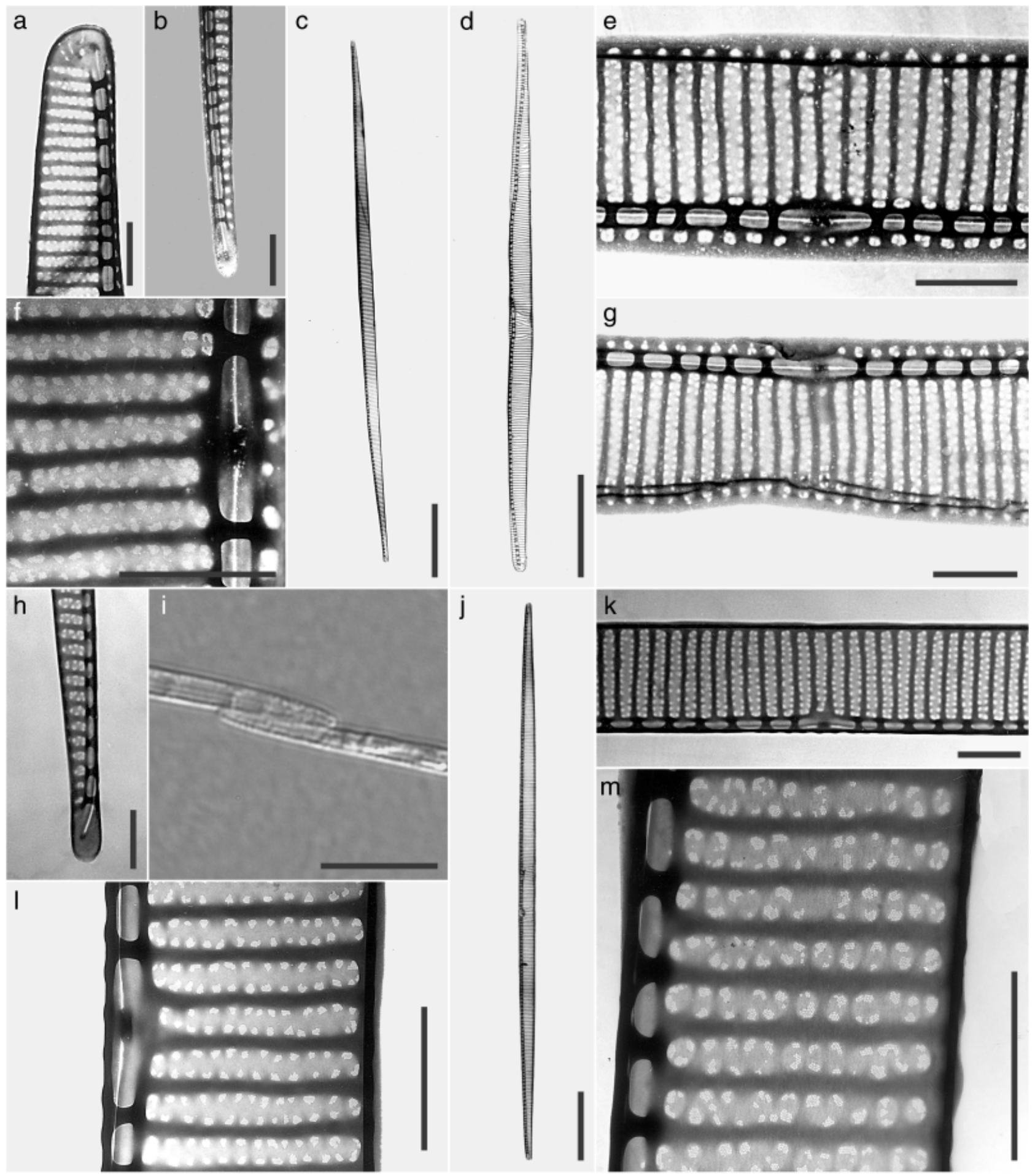

FIG. 5. Valve morphology in LM (i) and TEM $(\mathrm{a}-\mathrm{h}, \mathrm{j}-\mathrm{m})$ of F1 generation strains $(\mathrm{a}-\mathrm{g})$ and strains obtained by additional crosses (see Table 1) (h-m). (a) Cut-off end of a valve; strain F1-3. (b) Pointed end of a valve; strain F1-9. (c) Valve with isomorphic pointed ends. Strain F1-1. (d) Valve with heteromorphic ends. Strain F1-11. (e) Central portion of the valve in which the central larger interspace is visible. Strain F1-2. (f) Detail of the central portion of the valve. Strain F1-2. (g) Central portion of the valve. Strain F1-1. (h) Cell end. Strain F2-1. (i) Overlapping cell ends in girdle view. Strain BC2. (j) A valve. Strain F2-1. (k) Central portion of the valve. Strain F2-1. (l) Central portion of the valve. Strain F2-1. (m) Detail of the striae with larger poroids split into two to three sectors. Strain BC2. Scale bars: $10 \mu \mathrm{m}(\mathrm{c}-\mathrm{d}, \mathrm{j}), 1 \mu \mathrm{m}(\mathrm{a}-\mathrm{b}, \mathrm{e}-\mathrm{h}, \mathrm{k}-\mathrm{m}), 0.5 \mu \mathrm{m}(\mathrm{i})$. 


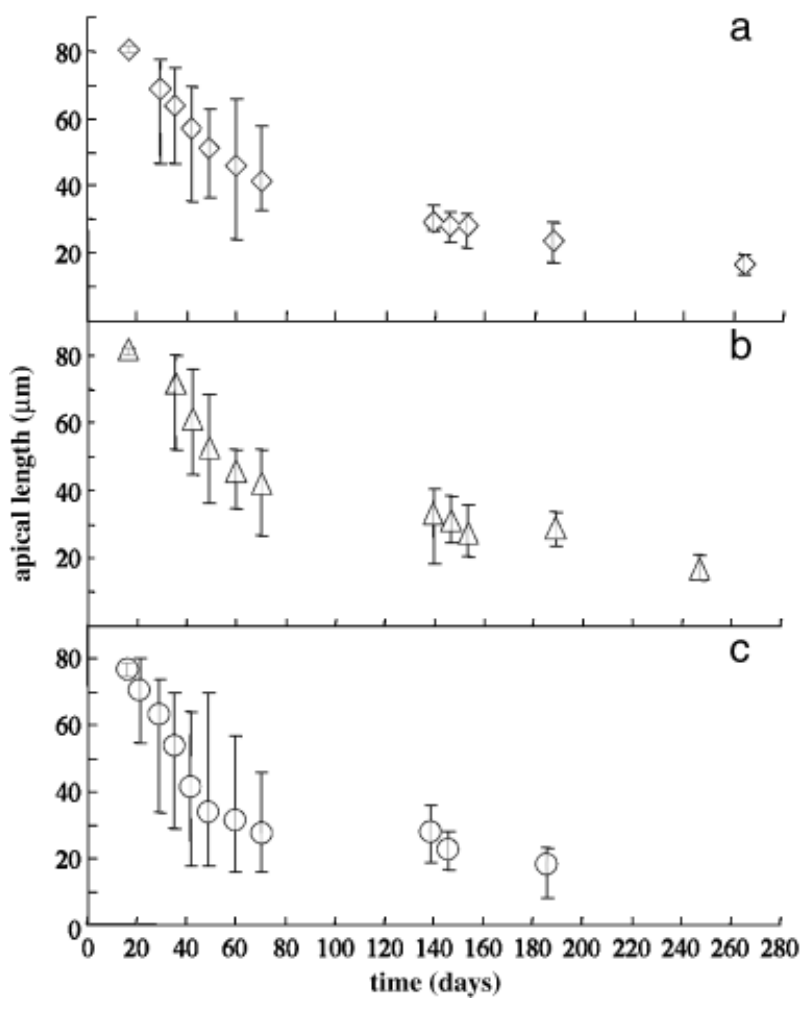

Fig. 6. Time course of average apical axis length decrease (vertical lines represent maximum and minimum values) in strains F1-5 (a), F1-13 (b), and F1-14 (c).

strains with this abnormal poroid arrangement were $1.3-1.9 \mu \mathrm{m}$.

Cell size reduction during vegetative growth. Cell size reduction patterns for the three $\mathrm{F} 1$ strains were similar. Cell length reduced rather quickly along the first 60 days after auxosporulation, until cells reached about $50 \%$ of their maximal size (Fig. 6). Size reduction then proceeded more slowly, even though experimental conditions remained unchanged. Strains died when average cell lengths were $<18 \mu \mathrm{m}$. Chains of variable length were produced by strains until the average length decreased below $30 \mu \mathrm{m}$; smaller cells were solitary and were often characterized by a more or less undulate shape.

Two strains (F1-5 and F1-14) grew extremely slowly during the first month after auxosporulation (Fig. 7, a and c). Subsequently, strains showed a general increase in growth rate to a maximum at $60-40 \mu \mathrm{m}$, depending on the strain. Growth rates then decreased again as cells approached the minimum viable size (Fig. 7, d-f). The average size reduction occurring per division was higher for larger cells, whereas the lowest values were recorded for cells whose average size was around 30-32 $\mu \mathrm{m}$ (Fig. 8, a-c).

\section{DISCUSSION}

Sexual reproduction. Pennate diatoms used to be considered homothallic (Drebes 1977). This assumption was based on the pioneering work of Geitler (1932), who described a homothallic life cycle for a few freshwater species (Mann et al. 1999). Further information on sexual reproduction generally relied on studies of natural populations, precluding determination of the mating system. Recently, however, extensive investigations carried out with cultures have demonstrated that many pennates are heterothallic (Chepurnov et al. 2004). Yet, a whole set of possible variants exist in the life cycle of pennate diatoms, including self-fertilization, the presence of strains that can act as both male and female, and the capability of forming polyploid auxospores (Chepurnov and Mann 1997, 1999, 2000, Mann et al. 1999).

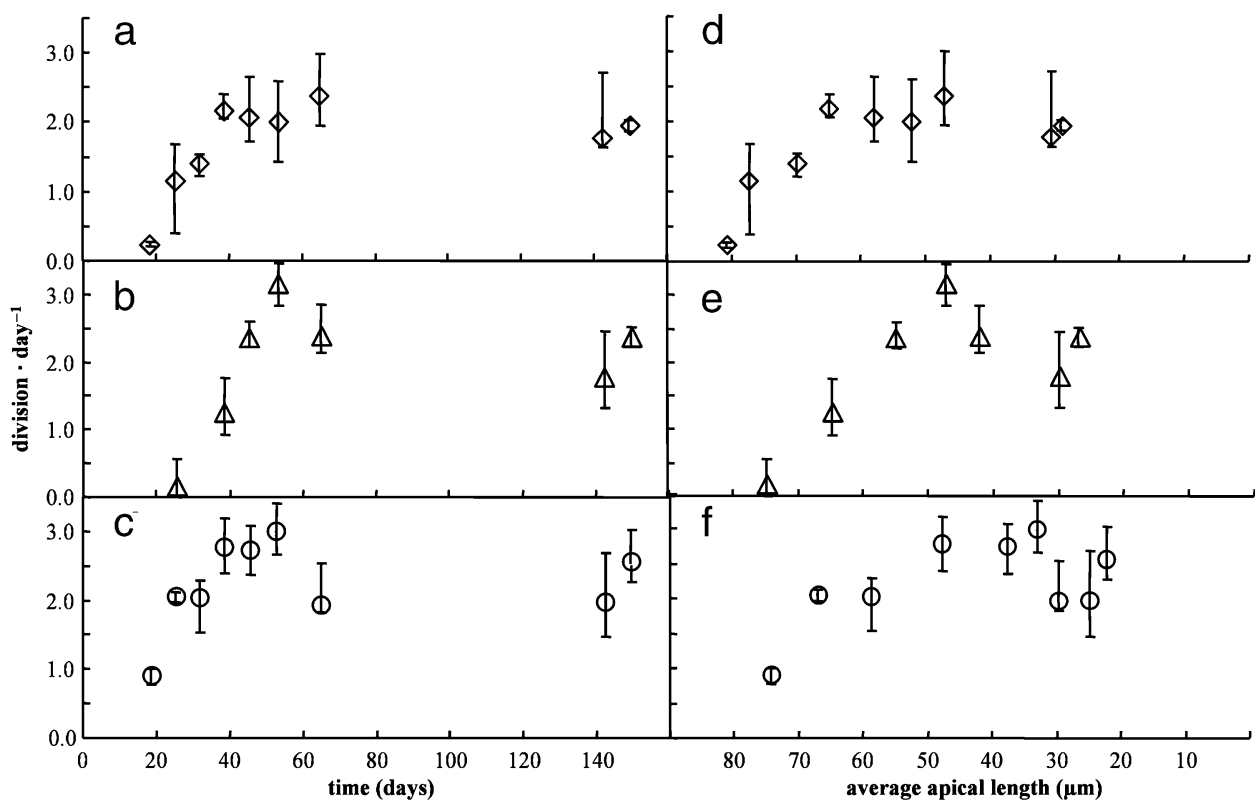

FIg. 7. Time course of growth rates (divisions $\cdot$ day $^{-1}$ ) plotted against time $(a-c)$ and average apical length $(\mathrm{d}-\mathrm{f})$ in strains F1-5 (a, d), F1-13 (b, e), and F1-14 (c, f). Symbols represent average values (vertical lines represent maximum and minimum values) of multiple growth rate estimates within two subsequent measurements of the population size. 


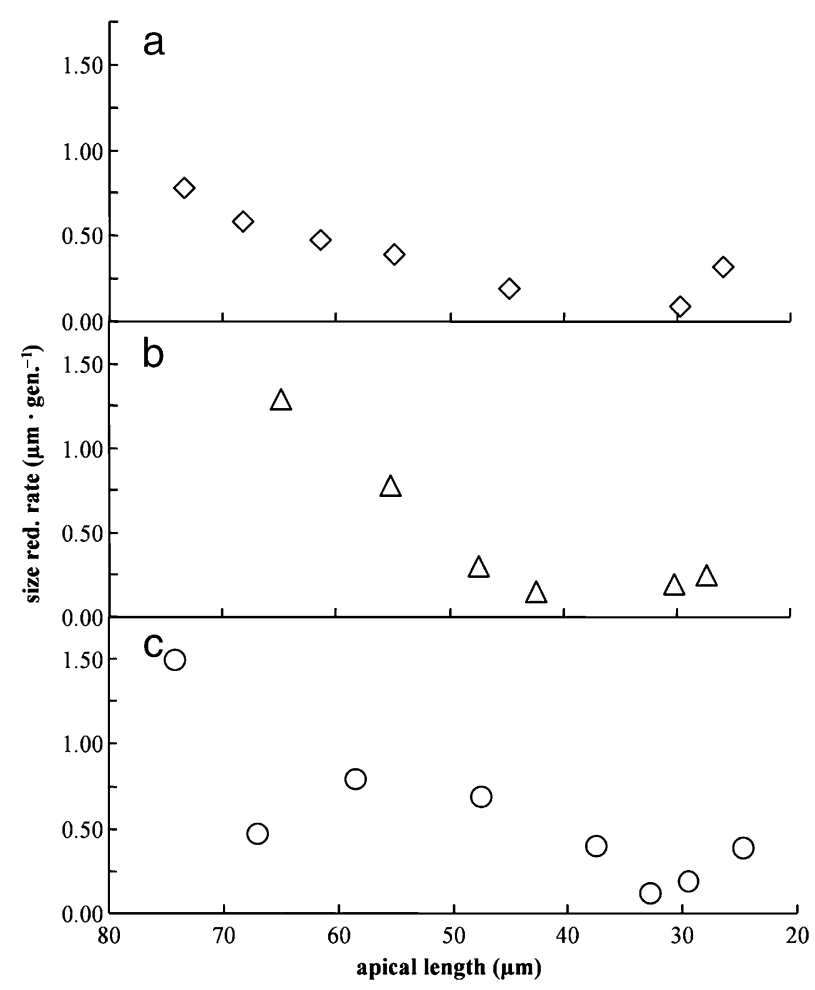

FIG. 8. Time course of size reduction rate $\left(\mu \mathrm{m} \cdot\right.$ generation $\left.^{-1}\right)$ plotted against average apical length in strains F1-5 (a), F1-13 (b), and F1-14 (c).

Our crossing experiments showed that $P$. delicatissima has a heterothallic sexual cycle, in which one gametangium produces two active gametes and the other one produces two sessile gametes. These characters support the assignment of $P$. delicatissima to the IA2-type of auxosporulation in Geitler's (1973) classification. A similar sexual cycle has been described for two other Pseudo-nitzschia species, P. multiseries (Hasle) Hasle and $P$. calliantha Lundholm, Moestrup and Hasle ( $=P$. pseudodelicatissima (Hasle) Hasle; Lundholm et al. 2003) (Davidovich and Bates 1998, Kaczmarska et al. 2000). Pairs of auxospores lying parallel to each other and attached to one gametangium have also been observed in $P$. subcurvata (Hasle) Hasle (= Nitzschia subcurvata Halse) by Fryxell et al. (1991). In $P$. delicatissima we observed the production of auxospores only when crossing strains belonging to opposite mating types, and cells of larger size were never produced within a monoclonal culture. However, the possibility of self-fertilization or conjugation within strains of the same mating type cannot be ruled out for all species of Pseudo-nitzschia, because longer cells were observed in a culture of $P$. brasiliana Lundholm, Hasle and Fryxell, in which most cells had reached the minimum size (Lundholm et al. 2002a). However, neither zygotes nor auxospores were detected in the culture. In P. calliantha, auxosporulation was observed in crosses between strains of the same mating type, thus suggesting the existence of bisexual strains
(Davidovich and Bates 1998, p. 134, as "P. pseudodelicatissima" clones ND-1 and ND-2). The existence of different mating systems has been demonstrated for species of the Sellaphora pupula (Kützing) Mereschkowsky species complex, where some species are capable of intraclonal reproduction (selfing) (Mann 1999, Behnke et al. 2004, Mann et al. 2004) as well as for Achnanthes longipes (Sabbe et al. 2004).

The auxospores of pennate diatoms sometimes have as many chloroplasts as vegetative cells (Chepurnov et al. 2002) and sometimes have twice as many, as in Pseudo-nitzschia calliantha $(=P . \quad$ pseudodelicatissima $)$, P. multiseries and P. pseudodelicatissima (Davidovich and Bates 1998, figs. 3-5), and P. delicatissima (present work). The number present depends on whether one or two gametes are formed per gametangium and, in diatoms producing two gametes, on whether or not chloroplast division occurs before the cytokinesis of meiosis I. The apparent loss of two of the four chloroplasts in the expanded auxospores of $P$. delicatissima is unusual but has also been reported for Nitzschia reversa W. Smith. Here, four chloroplasts are retained during auxospore elongation, but two sometimes degenerate later: Two chloroplasts are normally pigmented, whereas the two that later degenerate are contracted and dense (Mann 1993b). However, in other auxospores of $N$. reversa, all chloroplasts appear to survive. Further studies of the fate of individual chloroplasts during the formation of initial cells in Pseudo-nitzschia species are required.

There are a few differences in the modes of the sexual phase and/or in the ultrastructure of some life stages among Pseudo-nitzschia species. In P. delicatissima, each of the two gametes produced by one gametangium fuses with the gametes produced by the other one, thus yielding two zygotes for each pair of gametangia. In P. multiseries, the most commonly observed conjugation mode involves generally only one of the two couples of gametes per pair of gametangia and thus the formation of only one zygote (Davidovich and Bates 1998). Large silica scales have been reported on the nonmigrating gametes and on the early auxospore of $P$. multiseries (Kaczmarska et al. 2000). They are located both between the gametangium and the passive gamete and above. The lower scale persists during the early stages of auxospore development and has been interpreted as an anchoring mechanism. In $P$. delicatissima we never observed scales in SEM, and auxospores were attached to the cingular bands by a mucous pad. However, silicon was detected in the cell walls of the auxospores. The presence of siliceous scales has been reported on the auxospore of several centric diatoms (Drebes 1977, Round et al. 1990) and in the araphid pennates Rhabdonema arcuatum Kützing (von Stosch 1982), R. adriaticum Kützing (von Stosch 1957), and Gephyria media Arnott (Sato et al. 2004), whereas in the biraphid pennate Neidium affine (Ehrenberg) Pfitzer, a siliceous cap is produced, apparently through fusion of scale-like elements (Mann 1984). The presence/absence of siliceous components on sexual stages 
and the modes of auxospore development have been considered as valid characters for testing evolutionary relationships among lineages (von Stosch 1982). However, recent molecular phylogenies of diatoms (Kooistra et al. 2003) suggest a more complex picture in which the loss of silica scales seems to have occurred independently in several distantly related lineages.

In $P$. delicatissima, the sexual process takes about 4 days to complete. Similar results were reported for P. multiseries by Davidovich and Bates (1998), whereas a longer time (between 6 and 11 days) was recorded for the same species by Hiltz et al. (2000). Two to 4 days are needed in P. pseudodelicatissima and P. calliantha (Davidovich and Bates 1998). The observed differences might be attributed to the slightly different experimental conditions (photoperiod, irradiance) or to different concentrations of the parental strains in the culture vessels.

Size and sexual reproduction. Sexual reproduction in diatoms has been reported to occur within a critical size window, corresponding to $30 \%-40 \%$ of the maximum cell size (Drebes 1977, Round et al. 1990). However, this tenet has been challenged in recent years. In the centric diatom Thalassiosira weissflogii (Grunow) G. Fryxell and Hasle, spermatogenesis took place regardless the cell size range of the population (Armbrust et al. 1990), and an overlap in the size of initial cells and of gametangia has been reported for Coscinodiscus granii Gough (Schmid 1995). We have a limited number of measurements of the length of initial cells of $P$. delicatissima, and the maximum size recorded $(94 \mu \mathrm{m})$ might be exceeded by initial cells produced by parental strains larger than those used in our experiments as shown for several diatoms, both centric and pennate (Davidovich 1994, 2001). However, if we take $94 \mu \mathrm{m}$ as the maximum size of initial cells, it follows that $P$. delicatissima can become sexual over almost the entire size range (20\%-90\% of the maximum cell size), thus exceeding even the very wide size range for sexualization (from $23 \%$ to $70 \%$ of the maximum cell size) reported for P. multiseries (Davidovich and Bates 1998, Hiltz et al. 2000).

The peculiar size reduction process of diatoms and the presence of a defined size window setting the limits for the sexual cycle have been interpreted as an evolutionary strategy to allow diatoms to space sexual reproduction at intervals of $>1$ year (Lewis 1984). In this way, an endogenous clock independent from external cues recurring on a seasonal time scale would regulate induction of sexuality. Sexuality is a costly and risky event. Energy is allocated in gamete formation, and cells undergoing gametogenesis are "lost" as potential for increasing population biomass through vegetative divisions (Lewis 1984). Moreover, gametangia have to locate each other and gamete conjugation has to be successfully completed; observations show that some gametangia and gametes abort. All these considerations suggest that the sexual process cannot be continuous but is probably confined to times when the chances of success are maximal. Unfortunately, it is extremely difficult to track the occurrence of sexual stages in the natural environment. Sexual events can be detected indirectly by following changes in size class distributions within a population to detect the appearance and fate of larger post-auxospore cells (Mizuno and Okuda 1985, Mann 1988, Jewson 1992). Different scenarios of sexual timing have been found. The benthic diatom Cocconeis scutellum Ehrenberg var. ornata Grunow seems to undergo sexual reproduction on a yearly basis, large-sized cells occurring in late autumnwinter (Mizuno and Okuda 1985).

Longer cycles have been hypothesized for other diatoms. Nitzschia sigmoidea (Nitzsch) W. Smith and Tabellaria fenestrata (Lyngberg) Kützing seem to have life cycles of more than 5 years, and up to 40 years has been suggested for the freshwater centric diatom $A u$ lacoseira islandica var. helvetica (O. Müller) Simonsen, based on a reinterpretation (Mann 1988) of a longterm data set gathered by Nipkow (1927) in the sediments of Lake Zürich. A shorter cycle, of 4-6 years, has been postulated for Aulacoseira subarctica (O. Müller) Haworth (Jewson 1992). Both C. scutellum var. ornata and $A$. subarctica have a size window for sexualization in the lower range of their size. In contrast, $P$. delicatissima and $P$. multiseries undergo the sexual cycle over almost all the size ranges in culture, and this is likely to be true also in nature. However, the probability of successful encounters between gametangia in Pseudo-nitzschia may be lower than in other diatoms because Pseudo-nitzschia species are planktonic, living in a three-dimensional space; they do not release high numbers of motile gametes as in centric diatoms; and they are heterothallic, requiring the presence of opposite mating types for sexual reproduction. A wide size interval for sexualization may therefore be essential to allow an adequate chance of completing the life cycle.

The highest probability for encounters among gametangia most probably occurs during blooms, when cell concentrations are highest. We measured large numbers of cells during the peak phase of a $P$. delicatissima bloom in the Gulf of Naples in spring 2002, which was dominated by the same genotype as the strains examined in the present study; this showed a small peak of large cells (74-78 $\mu \mathrm{m}$ in length). Given that size reduction is rapid in larger cells, as we show here, the peak of large cells may be derived from a sexual event that occurred only a few days before the sampling date. However, to our knowledge, no attempts have been made to follow cell size distributions in the sea for Pseudo-nitzschia species and no one has reported finding sexual stages in natural populations. Cell concentrations of $P$. delicatissima during a bloom are in the order of thousands of cells $\cdot \mathrm{mL}^{-1}$ (Ribera d'Alcalà et al. 2004), one order of magnitude lower than in the mating experiments we conducted. If sexualization requires a threshold cell concentration to be accomplished, it is possible that sexual stages are present infrequently and in very small numbers in nature, and therefore they will be difficult to detect with 
routine phytoplankton counting procedures. It is also possible that conjugation occurs only in peculiar conditions, such as in ephemeral thin layers of physical discontinuity in the water column that favor cell aggregation and hence increase the probability of encounters (Rines et al. 2002).

Size reduction and vegetative growth. Pseudo-nitzschia delicatissima cultures kept at constant temperature and light conditions had different growth rates at different stages of size reduction. The growth rate was low when cells were long, then increased, and finally decreased when cells were small. A slower growth rate for larger cells is a common finding supported by the general allometric rule governing living organisms: The larger the body biomass, the slower the metabolic rate (Martin and Palumbi 1993). This trend has been reported for the centric diatom Skeletonema costatum, but in Ditylum brightwellii (West) Grunow the growth rate was constant over a wide size range and declined briskly only in small cells (Paasche 1973). In Thalassiosira decipiens (Grunow) Jørgensen and in the pennate Licmophora hyalina (Kützing) Grunow, growth rate seemed unaffected by size reduction (Paasche 1973). In all these species, only one linear dimension (cell diameter for centric and cell length for pennate species) was used to represent cell size variation. However, pervalvar and transapical axes can change during the cell reduction process (von Stosch and Drebes 1964, fig. 3, of Stephanopyxis turris (Greville et Anott) Ralfs), so that changes in cell volume (i.e. biomass) are not always be proportional to variations in cell diameter or length. In Thalassiosira weissflogii the highest growth rates were recorded for cells with the largest volume (Chisholm and Costello 1980 [ $=T$. fluvialitis Hustedt], Costello and Chisholm 1981), and this finding is apparently contradicting the allometric rule. However, it might also indicate that growth might not be strictly related to body biomass and that growth capability might be different in distinct stages of the species life cycle. The ratio between cell surface and volume $(\mathrm{S} / \mathrm{V})$ is related to the size and shape of the cell and takes into account the extension of the surface area through which nutrient uptake occurs. Potapova and Snoeijs (1997) found a clear annual cycle of the S/V ratios in natural population of Diatoma moniliformis Kützing. After the formation of large initial cells in early spring the $\mathrm{S} / \mathrm{V}$ ratio increased, and this coincided with the period of optimal growth in late spring. The $S / V$ ratio decreased afterward, to reach its minimum in the period of lowest cell abundance.

In $P$. delicatissima, the $\mathrm{S} / \mathrm{V}$ ratio covaries with the length of the apical axis, because the pervalvar and transapical axes remain almost constant during cell size reduction process. The $\mathrm{S} / \mathrm{V}$ ratios therefore increase steadily (but slowly) as cell diminish in size; however, growth rates increased only until the cells were between 50 and $30 \mu \mathrm{m}$ in length and diminished thereafter. This suggests a size interval most favorable for growth, possibly due to an optimal ratio between the size of the nucleus, which rules the physiological machinery of the cell, and the volume of the cytoplasm or to the activation of specific genetic pathways only in certain phases of the life cycle. It is interesting to report no records of the smaller cells of $P$. delicatissima (below $33 \mu \mathrm{m}$ in length) in natural samples collected over the years in the Gulf of Naples (D. Sarno and R. Siano, personal communication), whereas in culture cells down to $8 \mu \mathrm{m}$ in length were recorded. These small cells often present an abnormal morphology and could be more prone to attacks by parasites or experience a stronger pressure by grazers due to their reduced size and the incapability of forming chains; they also have a reduced growth rate.

The rate of size reduction in a population depends on two factors, the rate of decline in size per cell division and the growth rate. In P. delicatissima cultures, the highest size reduction rate was recorded when cell were large, between the maximum dimensions (in the initial cells) and about $50 \%$ of the maximum, which was reached by our strains in about 2 months. Considering that the growth rates of the largest cells are relatively low, we can deduce that size reduction at each division step was relatively high. Growth rates increased afterward, but the size reduction per generation decreased. Differences in size reduction patterns among diatoms are well known and depend on the girdle band thickness, rigidity, on whether they are open or not, and on where the new valves are formed within the girdle cylinder (Crawford 1980). A study considering 13 species of pennate and 1 centric diatom pointed out that species different in size showed different size reduction rates per generation, with larger species reducing their size faster than smaller ones (Mizuno 1991). Our results support the conclusion that differences in size reduction per cell division might occur also within the same species. The presence of open cingular bands in $P$. delicatissima and the possibility that they might be thinner, and thus more elastic, in smaller cells might account for the observed differences.

In $P$. delicatissima, the lengths of the pervalvar and transapical axes were usually constant throughout size reduction, and no differences were observed in the stria, fibula, and poroid densities. Only when very small sizes were reached did some cells acquire abnormal shapes, with an undulate cell outline. This, however, did not compromise the sexual process or vegetative division. Wide morphological variation has been described for Pseudo-nitzschia galaxiae Lundholm and Moestrup, where longer cells are linear, mid-sized cells are lanceolate with rostrate ends, and the smallest cells have an almost oval outline with tapered ends (Lundholm and Moestrup 2002, Cerino et al. 2005). The different size classes of $P$. galaxiae also show different seasonality. Medium to large cells bloom in April-May and August-September, whereas smaller cells bloom in March, suggesting that distinct size classes might thrive under different environmental conditions or that their peculiar seasonal distribution might reflect the timing of sexual reproduction (Cerino et al. 
2005). Unfortunately, it will be extremely difficult to gather reliable data on size class distribution of $P$. delicatissima at sea, due to the impossibility to distinguish among the different genotypes in LM (Orsini et al. 2004). The results of this investigation, however, provide some insights on the life cycle of this species in the natural environment. Our growth experiments were performed at nonlimiting environmental conditions comparable with those recorded at sea during the spring bloom. We might expect that $P$. delicatissima population will experience a detectable size reduction, of up to approximately $20 \mu \mathrm{m}$, during a spring bloom lasting on average $3-4$ weeks. The frequency distribution curves of the population should therefore be skewed toward smaller size classes at the end of the bloom. Nevertheless, if our assumption that sexual reproduction occurs during the bloom is correct, we should also find peaks of larger cells, which compensate the size reduction of the population due to the high growth rates during the bloom. Our experimental data indicate that $P$. delicatissima cells should take less than 1 year to reach the minimal size. Although estimates of growth rates in situ for Pseudo-nitzschia species are not available, it is unlikely that the high division rate accounting for the development of a bloom will be maintained over the whole year. Cells might enter in a quiescent phase either in the water column or in the sediment, during which cell division, and therefore size reduction, are markedly reduced.

Morphology. Pseudo-nitzschia delicatissima is colonial, with linear-lanceolate to slightly rhomboid frustules, rounded apices in valvar view, and linear frustules with slightly sigmoid ends in girdle view. Previous descriptions (Hasle 1965 [as Nitzschia actydrophila], Hasle et al. 1996, Skov et al. 1999) give cell dimensions of approximately $2 \mu \mathrm{m}$ wide and $40-78 \mu \mathrm{m}$ long. The cell overlaps within chains range between $1 / 7$ and $1 / 9$ of the total cell length. Cells have a larger central interspace between the fibulae and central raphe endings, and the valves have two rows of poroids per stria; the ultrastructural features of striae and fibulae are listed in Table 2. The ultrastructural features of the genetically related parental strains used in our study (Orsini et al. 2004) fit this description. The number and ornamentation of cingular bands also fit what was reported by Hasle et al. (1996), except that we generally observed the second band to bear only one row of irregular poroids. The TEM analysis of our P. delicatissima showed the presence of cells with pointed apices or heteropolar valves with one pointed and one rounded apex in the F1 generation, in contrast to the isopolarity and rounded apices previously described. These strains were prepared for TEM within a few weeks from culture establishment by isolation of a large initial cell, and it might be that the cell ends regain their rounded apices as the cell size decreases. However, our results indicate that large $P$. delicatissima cells could be misidentified in LM with $P$. pseudodelicatissima, which is characterized by pointed apices. We also recorded variability in the poroid arrangement within the striae of a few clones obtained from laboratory crosses. The irregular poroid arrangement (a tendency to form one row of poroids per stria in certain parts of the valve) was comparable with that found in a strain belonging to a different $P$. delicatissima ITS type than that examined in this study (Orsini et al. 2004). However, the cells we examined in the present study were always $\leq 2 \mu \mathrm{m}$ in width, whereas in other strains in which this peculiar poroid arrangement was observed had wider valves (Lundholm et al. 2002b, Orsini et al. 2004). Differences in poroid arrangement have been reported for other strains designed as P. delicatissima (Skov et al. 1999, figs. 9I and 9J), and it is thus important to gather a more extensive pool of data on the range of variation of gross and fine morphological features that might help us to correctly separate the different cryptic species within the $P$. delicatissima complex.

We thank Professor David G. Mann for help and suggestions provided in the revision process, Santiago Fraga for providing P. delicatissima strain $14 \mathrm{~V}$, Diana Sarno for much precious advice, Mario De Stefano for SEM analyses, and Gandi Forlani for helping in TEM preparations. Some of this work is part of a Ph.D. thesis in Algal Biology (University of Messina, Italy, Stazione Zoologica "A. Dohrn" Napoli, Italy) of Luisa Orsini; other sections form part of the Ph.D. program in Marine Phytoplankton Life Cycles (Open University London, England, Stazione Zoologica "A. Dohrn" Napoli, Italy) of Alberto Amato.

Armbrust, E. V., Chisholm, S. W. \& Olson, R. J. 1990. Role of light and the cell cycle on the induction of spermatogenesis in a centric diatom. J. Phycol. 26:470-8.

Behnke, A., Friedl, T., Chepurnov, V. A. \& Mann, D. G. 2004. Reproductive compatibility and rDNA sequence analyses in the Sellaphora pupula species complex (Bacillariophyta). J. Phycol. 40:193-208.

Cerino, F., Orsini, L., Sarno, D., Dell'Aversano, C., Tartaglione, L. \& Zingone, A. 2005. The alternation of different morphotypes in the seasonal cycle of the toxic diatom Pseudo-nitzschia galaxiae. Harmful Algae 4:33-48.

Chepurnov, V. A. \& Mann, D. G. 1997. Variation in the sexual behaviour of natural clones of Achnanthes longipes (Bacillariophyta). Eur. J. Phycol. 32:147-54.

Chepurnov, V. A. \& Mann, D. G. 1999. Variation in the sexual behaviour of Achnanthes longipes (Bacillariophyta). II. Inbred monoecious lineages. Eur. J. Phycol. 34:1-11.

Chepurnov, V. A. \& Mann, D. G. 2000. Variation in the sexual behaviour of Achnanthes longipes (Bacillariophyta). III. Progeny of crosses between monoecious and unisexual clones. Eur. J. Phycol. 35:213-23.

Chepurnov, V. A., Mann, D. G., Sabbe, K. \& Vyverman, W. 2004. Experimental studies on sexual reproduction in diatoms. Int. Rev. Cytol. 237:91-154.

Chepurnov, V. A., Mann, D. G., Vyverman, W., Sabbe, K. \& Danielidis, D. B. 2002. Sexual reproduction, mating system, and protoplast dynamics of Seminavis (Bacillariophyceae). J. Phycol. 38:1004-19.

Chisholm, S. W. \& Costello, J. C. 1980. Influence of environmental factors and population composition on the timing of cell division in Thalassiosira fluviatilis (Bacillariophyceae) grown on light/dark cycles. J. Phycol. 16:375-83.

Costello, J. C. \& Chisholm, S. W. 1981. The influence of cell size on the growth rate of Thalassiosira weissflogii. J. Plankton Res. $3: 415-9$. 
Crawford, R. M. 1980. Some considerations of size reduction in diatom cell walls. In Ross, R. [Ed.] Proceedings of the Sixth Symposium on Recent and Fossil Diatoms. Otto Koeltz Science Publisher, Koenigstein, pp. 253-61.

Davidovich, N. A. 1994. Factors controlling the size of initial cells in diatoms. Russian J. Plant Physiol. 41:220-4.

Davidovich, N. A. 2001. Species-specific sizes and size range of sexual reproduction in diatoms. In Economou-Amilli, A. [Ed.] Proceedings of the 16th International Diatom Symposium 2000. Amvrosius Press, Athens, pp. 191-6.

Davidovich, N. A. \& Bates, S. 1998. Sexual reproduction in the pennate diatom Pseudo-nitzschia multiseries and P. pseudodelicatissima (Bacillariophyceae). J. Phycol. 34:126-37.

Drebes, G. 1977. Sexuality. In Werner, D. [Ed.] The Biology of Diatoms. Blackwell Scientific Publications, Oxford, pp. 250-83.

Edlund, M. B. \& Stoermer, E. F. 1997. Ecological, evolutionary, and systematic significance of diatom life histories. J. Phycol. 33:897-918

French, F. W. III \& Hargraves, P. E. 1985. Spore formation in the life cycles of the diatoms Chaetoceros diadema and Leptocylindrus danicus. J. Phycol. 21:477-83.

Fryxell, G. A., Garza, S. A. \& Roelke, D. L. 1991. Auxospore formation in an Antarctic clone of Nitzschia subcurvata Hasle. Diatom Res. 6:235-45.

Gallagher, J. C. 1983. Cell enlargement in Skeletonema costatum (Bacillariophyceae). J. Phycol. 19:539-42.

Geitler, L. 1932. Der Formwechsel der pennaten Diatomeen (Kieselalgen). Arch. Protistenk. 78:1-226.

Geitler, L. 1973. Auxosporenbidung und Systematik bei pennaten Diatomeen und die Zytologie von Cocconeis-Sippen. Osterr. Bot. Z. 122:299-321.

Geitler, L. 1979. On some peculiarities in the life history of pennate diatoms hitherto overlooked. Am. J. Bot. 66:91-7.

Guillard, R. R. L. 1983. Culture of phytoplankton for feeding marine invertebrates. In Berg, C. J. J. [Ed.] Culture of Marine Invertebrates Selected Readings. Hutchinson Ross Publishing Co., Stroudsberg, PA, pp. 108-32.

Hasle, G. R. 1965. Nitzschia and Fragilariopsis species studied in the light and electron microscopes. II. The group Pseudonitzschia. Skr. Nor. Vidensk-Akad. Oslo I. Mat-Naturvidensk. Kl. 18:1-45.

Hasle, G. R. 2002. Are most of the domoic acid-producing species of the diatom genus Pseudo-nitzschia cosmopolites? Harmful Algae 1:137-46.

Hasle, G. R., Lange, C. B. \& Syvertsen, E. E. 1996. A review of Pseudo-nitzschia, with special reference to the Skagerrak, North Atlantic, and adjacent waters. Helgol. Meeresunters. 50:131-75.

Hasle, G. R. \& Syvertsen, E. E. 1997. Marine diatoms. In Tomas, C. R. [Ed.] Identifying Marine Phytoplankton. Academic Press, San Diego, pp. 5-385.

Hiltz, M., Bates, S. S. \& Kaczmarska, I. 2000. Effect of light:dark cycles and cell apical length on the sexual reproduction of the pennate diatom Pseudo-nitzschia multiseries (Bacillariophyceae) in culture. Phycologia 39:59-66.

Jewson, D. H. 1992. Size reduction, reproductive strategy and the life strategy of a centric diatom. Phil. Trans. R. Soc. Lond. B 336:191-213.

Kaczmarska, I., Bates, S. S., Ehrman, J. M. \& Léger, C. 2000. Fine structure of the gamete, auxospore and initial cell in the pennate diatom Pseudo-nitzschia multiseries (Bacillariophyta). Nova Hedw. 71:337-57.

Kooistra, W. H. C. F., De Stefano, M., Mann, D. G. \& Medlin, L. K. 2003. The phylogeny of the diatoms. Progr. Mol. Subcell. Biol. 33:59-97.

Lewis, W. M. Jr. 1984. The diatom sex clock and its evolutionary importance. Am. Nat. 123:73-80.

Lundholm, N., Hasle, G. R., Fryxell, G. A. \& Hargraves, P. E. 2002a. Morphology, phylogeny and taxonomy of species within the Pseudo-nitzschia americana complex (Bacillariophyceae) with descriptions of the two new species $P$. brasiliana and P. linea. Phycologia 41:480-97.

Lundholm, N. \& Moestrup, Ø. 2002. The marine diatom Pseudonitzschia galaxiae sp. nov. (Bacillariophyceae), morphology and phylogenetic relationships. Phycologia 41:594-605.
Lundholm, N., Moestrup, Ø., Hasle, G. R. \& Hoef-Emden, K. 2003. A study of the Pseudo-nitzschia pseudodelicatissima/cuspidata complex (Bacillariophyceae): what is P. pseudodelicatissima? J. Phycol. 39:797-813

Lundholm, N., Moestrup, Ø., Scholin, C. \& Miller, P. 2002b. Genetic and morphological variation of Pseudo-nitzschia cf. delicatissima, with description of a new species. In Book of Abstracts, Tenth International Conference on Harmful Algae. St. Pete Beach, Florida, USA., p. 177.

Mann, D. G. 1984. Auxospore formation and development in Neidium (Bacillariophyceae). Br. Phycol. J. 19:319-31.

Mann, D. G. 1988. Why didn't Lund see sex in Asterionella? A discussion of the diatom life cycle in nature. In Round, F. E. [Ed.] Algae and the Aquatic Environment. Biopress, Bristol, pp. 385412.

Mann, D. G. 1993a. Patterns of sexual reproduction in diatoms. Hydrobiologia 269/270:11-20.

Mann, D. G. 1993b. Sexual reproduction in a marine member of the Bacillariophyceae. Diatom Res. 8:109-16.

Mann, D. G. 1999. The species concept in diatoms. Phycologia $38: 437-95$

Mann, D. G., Chepurnov, V. A. \& Droop, S. J. M. 1999. Sexuality, incompatibility, size variation and preferential polyandy in natural populations and clones of Sellaphora pupula (Bacillariophyceae). J. Phycol. 35:152-70.

Mann, D. G., Chepurnov, V. A. \& Idei, M. 2003. Mating system, sexual reproduction, and auxosporulation in the anomalous raphid diatom Eunotia (Bacillariophyta). J. Phycol. 39:1067-84

Mann, D. G., McDonald, S. M., Bayer, M. M., Droop, S. J. M., Chepurnov, V. A., Loke, R. E., Ciobanu, A. \& Du Buf, J. M. H. 2004. The Sellaphora pupula species complex (Bacillariophyceae): morphometric analysis, ultrastructure and mating data provide evidence for five new species. Phycologia 43: $459-82$

Martin, A. P. \& Palumbi, S. R. 1993. Body size, metabolic rate, generation time and molecular clock. Proc. Natl. Acad. Sci. USA 90:4087-91.

McQuoid, M. R. \& Hobson, L. A. 1996. Diatom resting stages. J. Phycol. 32:889-902

Mizuno, M. 1991. Influence of cell volume on the growth and size reduction of marine and estuarine diatoms. J. Phycol. 27: $473-8$.

Mizuno, M. \& Okuda, K. 1985. Seasonal change in the distribution of cell size of Cocconeis scutellum var. ornata (Bacillariophyceae) in relation to growth and sexual reproduction. J. Phycol. $21: 547-53$

Nagai, S., Hori, Y., Manabe, T. \& Imai, I. 1995. Restoration of cell size by vegetative cell enlargement in Coscinodiscus wailesii (Bacillariophyceae). Phycologia 34:533-5.

Nipkow, F. 1927. Über das Verhalten der Skelette planktischer Kieselalagen im Plankton des Zürich- und Baldeggersees. Z. Hydrol. Hydrogr. Hydrobiol. 4:71-120.

Orsini, L., Procaccini, G., Sarno, D. \& Montresor, M. 2004. Multiple rDNA ITS-types within the diatom Pseudo-nitzschia delicatissima (Bacillariophyceae) and their relative abundances across a spring bloom in the Gulf of Naples. Mar. Ecol. Prog. Ser. 271:87-98.

Paasche, E. 1973. The influence of cell size of growth rate, silica content, and some other properties of four marine diatom species. Norw. J. Bot. 20:151-62.

Potapova, M. \& Snoeijs, P. 1997. The natural life cycle in wild populations of Diatoma moniliformis (Bacillariophyceae) and its disruption in an aberrant environment. J. Phycol. 33:924-37.

Ribera d'Alcalà, M., Conversano, F., Corato, F., Licandro, P., Mangoni, O., Marino, D., Mazzocchi, M. G., Modigh, M., Montresor, M., Nardella, M., Saggiomo, V., Sarno, D. \& Zingone, A. 2004. Seasonal patterns in plankton communities in a pluriannual time series at a coastal Mediterranean site (Gulf of Naples): an attempt to discern recurrences and trends. Sci. Mar 68(suppl 1):65-83.

Rines, J. E. B., Donaghay, P. L., Dekshenieks, M. M., Sullivan, J. M. \& Twardowski, M. S. 2002. Thin layers and camouflage: hid- 
den Pseudo-nitzschia spp. (Bacillariophyceae) populations in a fjord in the San Juan Islands, Washington, USA. Mar. Ecol. Prog. Ser. 225:123-37.

Round, F. E., Crawford, R. M. \& Mann, D. G. 1990. The Diatoms. Biology and Morphology of the Genera. Cambridge University Press, Cambridge, UK, 747 pp.

Sabbe, K., Chepurnov, V. A., Vyverman, W. \& Mann, D. G. 2004 Apomixis in Achnanthes (Bacillariophyceae): development of a model system for diatom reproductive biology. Eur. J. Phycol. 39:327-41.

Sato, S., Nagumo, T. \& Tanaka, J. 2004. Auxospore formation and the morphology of the initial cell of the marine araphid diatom Gephyria media (Bacillariophyceae). J. Phycol. 40:684-91.

Schmid, A. M. M. 1995. Sexual reproduction in Coscinodiscus granii Gough in culture: a preliminary report. In Marino, D. \& Montresor, M. [Eds.] Proceedings of the 13th International Diatom Symposium. Biopress, Bristol, pp. 139-59.
Skov, J., Lundholm, N., Moestrup, Ø. \& Larsen, J. 1999. Potentially toxic phytoplankton. 4. Genus Pseudo-nitzschia (Diatomophyceae/Bacillariophyceae). In Lindley, J. A. [Ed.] ICES Identification Leaflets for Plankton. ICES, Copenhagen, pp. 2-23.

Theriot, E. 1992. Clusters, species concepts, and morphological evolution of diatoms. Syst. Biol. 41:141-57.

von Stosch, H. A. 1957. Kann die oogame Araphidee Rhabdonema adriaticum als Bindeglied zwischen den beiden grossen Diatomeengruppen angesehen werden? Ber. dt. Bot. Ges. 71:241-9.

von Stosch, H. A. 1965. Manipulierung der Zellgrösse von Diatomeen in Experiment. Phycologia 5:21-44.

von Stosch, H. A. 1982. On auxospore envelopes in diatoms. Bacillaria 5:127-56.

von Stosch, H. A. \& Drebes, G. 1964. Entwicklungsgeschichtliche Untersuchungen an zentrischen Diatomeen IV. Die Planktondiatomee Stephanopyxis turris-ihre Behandlung und Entwicklungsgeschichte. Helgol. Wiss. Meeresunters. 11:1-48. 
This document is a scanned copy of a printed document. No warranty is given about the accuracy of the copy. Users should refer to the original published version of the material. 